\title{
ANALISIS KEMAMPUAN BERBICARA SISWA KELAS II MELALUI MODEL PEMBELAJARAN THINK TALK WRITE DI SDN 007 SUNGAI PINANG SAMARINDA
}

\author{
Sri Mulyati \\ Program Studi Pendidikan Guru SD Universitas Mulawarman Samarinda \\ bundafanny1976@gmail.com
}

\begin{abstract}
The research aimed at finding out speaking ability of second grade elementary students by using Think Talk Write learning model. The data retrieval was carried out for four days. The problem was lack of teachers' innovation in improving students' speaking ability so the researcher decided to carry out this model. The research method was descriptive qualitative. Primary data was taken from this research result and secondary data was taken from published journals. Data analysis techniques were triangulation and data reduction from interview, observations, students' activities, and students' presentation results. The result of this study showed that on the first day of observation the students were still in low category, while on the second day to the fourth day, 25 students were in fast category and only 2 students were in medium category. Based on this result, it can be concluded that Think Talk Write learning model can improve speaking ability of second grade elementary students. Keyword: Speaking ability, Learning Model, Think Talk Write
\end{abstract}

\section{Pendahuluan}

Pembelajaran Bahasa pada dasarnya merupakan sebuah aktivitas yang sistematik dan terencana. Dikatakan sistemik karena di dalamnya terdapat seperangkat subsistem yang saling berkaitan dan berinteraksi secara fungsional untuk mencapai tujuan pembelajaran yang telah ditetapkan. Dikatakan sistematik karena dalam pelaksanaannya terdapat tatanan dan tahapan yang bersifat prosedural dan berhubungan secara kronologis-kausatif. Selanjutnya dikatakan terencana karena dalam pembelajaran terlihat jelas dan tegas adanya dasar, arah dan tujuan serta sasaran yang ingin dicapai. Untuk melaksanakan pembelajaran perlu perencanaan yang harus dipersiapkan dan evaluasi sebagai tindak lanjut untuk mengetahui berhasil tidaknya pembelajaran tersebut.

Pembelajaran Bahasa Indonesia dikatakan berhasil terletak pada strategi dan metode yang digunakan. Hal ini cukup beralasan karena pembelajaran Bahasa Indonesia selama ini belum mencapai hasil yang diinginkan, yaitu mampu berkomunikasi dengan baik dan benar secara lisan maupun tulis sehingga semua pihak perlu memikirkan bagaimana pembelajaran yang baik agar tujuan yang telah ditetapkan dalam kurikulum dapat tercapai. Pembelajaran tersebut adalah perubahan tingkah laku yang relatif permanen dan tingkah laku potensial yang diakibatkan adanya pembelajaran yang baik untuk Bahasa Indonesia.(Solchan, 2012).

Pernyataan di atas di dukung dengan hasil penelitian yang telah dilakukan oleh Rahmat B, 2012, memberikan batasan bahwa berbicara adalah kemampuan mengucapkan bunyi-bunyi artikulasi atau kata-kata untuk mengekspresikan, menyatakan, serta menyampaikan pikiran, gagasan dan perasaan. Sedangkan sebagai bentuk atau wujudnya berbicara disebut sebagai alat untuk menkomunikasikan gagasan-gagasan yang disusun serta dikembangkan sesuai dengan kebutuhankebutuhan sang pendengar atau penyimakyang pada hakekatnya berbicara merupakan ungkapan pikiran dan perasaan seseorang dalam bentuk bunyi-bunyi bahasa. Kemampuan berbicara adalah kemampuan mengucapkan bunyi-bunyi artikulasi atau mengucapkan kata-kata untuk mengekspresikan,menyatakan,

menyampaikan pikiran, gagasan, dan perasaan. Pendengar penerima informasi melalui rangkaian nada, tekanan, dan penempatan penyendian. Jika komunikasi 
berlangsung tatap muka, berbicara ini dapat dibantu dengan mimik dan pantomimik pembicara sedangkan keterampilan berbicara dapat diklasifikasikan berdasarkan situasi, tujuan, dan jumlah pendengar, peristiwa khusus yang melatari dan metode penyampaian. Berdasarkan situasi pembicaraan, jenis berbicara terdiri atas berbicara formal dan berbicara informal. Berdasarkan situasi yang formal, berbicara dapat diklasifikasikan dalam jenis diskusi kelompok, panel, simposium, seminar, konfrensi, dan brainstorming. Adapun berdasarkan metode penyampaiannya, dikenal metode mendadak, tanpa persiapan, membaca naskah dan menghafal. (Solchan, 2012).

\section{Kemampuan berbicara sangat} penting dilatih sejak dini sehingga pembelajaran bahasa Indonesia diberlakukan sejak pendidikan kelas awal, permasalahan yang kerap terjadi di pendidikan seolah dasar (SD) terkait bagaimana memberikan atau mentransfer ilmu berbahasa baik kemampuan maupun keterampilan kepada siswa kelas awal, sehingga beberapa siswa khususnya kelas awal ada yang belum memliki kemampuan berbahasa dengan benar. Zaman era 4.0 kemampuan berbahasa sangat penting dikembangkan sejak dini karena perkembangan zaman serta metode pembelajaran yang semakin pesat menuntut siswa kelas awal memliki kemampuan berbahasa dan keterampilan berbahasa, adapun tujuan pembelajaran berbicara di SD kelas awal dikelompokkan 1) melatih keberanian siswa, (2) melatih siswa menceritakan pengalaman dan pengetahuannya, (3) melatih menyampaikan pendapat dan (4) membiasakan siswa untuk bertanya. (Solchan, 2012).

Kurikulum 2013 kurikulum yang berbasis kompetensi dan karakter secara terpadu yang merupakan penyempurnaan dari kurikulum Tingkat Satuan Pendidikan (KTSP). Kurikulum ini dipandang sesuai dengan program Pendidikan Bahasa Indonesia bagi anak Sekolah Dasar (SD). Perbedaan tersebut terlihat pada karakteristik yakni pendekatan saintifik dan pendekatan autentik dalam pembelajaran. Metode Pendidikan yang diterapkan tidak lagi berupa pengajaran demi kelulusan ujian, namun pendidikan yang menyeluruh memperhatikan kemampuan siswa yang meliputi; sosial, watak, budi pekerti dan kecintaan budaya dasar. Implementasi kurikulum 2013 diharapkan mampu menghasilkan generasi yang produktif, kreatif dan inovatif untuk bersaing dalam dunia internasional. Begitu pula dengan pembelajaran Bahasa Indonesia di Sekolah Dasar (SD) khususnya untuk pembelajaran berbicara.(Solchan, 2012).

Permasalahan yang terjadi berdasarkan hasil observasi awal yang telah dilakukan di SDN 007 Sei Pinang, keberanian siswa untuk menyampaikan gagasan atau ide, menceritakan pengalaman,menyampaikan pendapat dan kemampuan bertanya yang dimiliki sangat kurang sehingga siswa cenderung menjdi lebih pasif sehingga kelas menjadi tidak aktif. Sehingga sangat perlu untuk menciptakan suasana yang dapat mendorong anak untuk berbicara, guru dapat membangkitkan sikap positif anak terhadap kegiatan berbicara di dalam kelas. Yang paling penting adalah guru berusaha menciptakan suasana belajar yang inovatif yang dapat membangkitkan minat anak dalam belajar berbicara.

Pembelajaran yang inovatif dan menyenangkan sangat membantu untuk meningkatkan kemampuan berbicara siswa sehingga diperlukan guru untuk memahami pentingnya bahasa lisan dalam proses belajar, tanggapan guru terhadap bahasa yang digunakan siswa akan memperlihatkan penghargaan guru terhadap bahasa dan belajar,dan seorang guru sebaiknya memberikan kesempatan seluas-luasnya kesempatan kepada siswa untuk berbicara. Untuk menciptakan pembelajaran yang inovatif diperlukan model pembelajaran yang relevan dan sesuai dengan tujuan pembelajaran. model pembelajaran yang relevan dengan kemampuan berbicara siswa yakni Think Talk Write melalui kegiatan memprediksi sebuah buku cerita.

Observasi awal dilaksanakan pada siswa kelas awal (Kelas II) SDN 007 Kecamatan Sungai Pinang dimana kemampuan berbicara siswa sangat kurang sehingga perlu melakukan analisis kemampuan berbicara siswa kelas awal 
berdasarkan teori perkembangan Piaget menyatakan bahwa anak usia $7-8$ tahun berada pada fase Operasional konkret yaitu anak sudah dapat membentuk operasioperasi mental atas pengetahuan yang mereka miliki. Mereka dapat menambah, mengurangi dan mengubah. Operasi ini memungkinkannya untuk dapat memecahkan masalah yang dihadapinya adalah permasalahan yang konkret. Dari sisi kognitif, siswa kelas II berada pada tahap operasional konkret dimana anak sudah dapat berpikir logis dan sudah mengerti konsep rasional. Sehingga anak sudah mulai mampu berbicara lancar walaupun untuk menyampaikan pendapat atau gagasan masih belum terlatih. Pada tahap ini anak akan mengalami kesulitan apabila diberi tugas yang menuntutnya untuk mencari sesuatu yang sifatnya tersembunyi. (Mulyani Sumantri, 2014).

Terkait permasalahan diatas maka perlu dilakukan analisis terhadap kemampuan berbicara siswa kelas awal dengan menggunakan model pembelajaran Think Talk Write yang relevan dengan tujuan pembelajaran dan fokus pada mengulang kalimat sederhana, menjawab pertanyaan sederhana, menceritakan kembali cerita yang pernah didengarnya. Kemampuan ini terdiri dari beberapa aspek yaitu: tata bahasa kalimat, kosa kata (pemilihan kata), kelancaran, kenyaringan suara dan sikap gerak mimik saat berbicara.

\section{METODE PENELITIAN}

Penelitian ini menggunakan jenis penelitian deskriptif kualitatif dengan metode deskriptif. Metode yang digunakan dalam penelitian ini bersifat deskriptif dengan pendekatan penelitian kualitatif. Penelitian deskriptif kualitatif merupakan salah satu dari jenis penelitian yang termasuk dalam jenis penelitian kualitatif.

Metode deskriptif dipilih karena penelitian yang dilakukan berkaitan dengan peristiwa-peristiwa yang terjadi dan sedang diteliti. Adapun tujuan dari penelitian ini adalah untuk mendeskripsikan, mengungkapkan kejadian atau fakta, keadaan, fenomena, situasi sosial di kelas secara sistematis serta hubungan antar fenomena yang diteliti yakni permasalahan mengenai kemampuan berbicara siswa kelas II melalui model pembelajaran Think Talk Write di SDN 007 Sungai Pinang Samarinda.

Desain penelitian ini merupakan studi deskriptif analitis yang bertujuan mendeskripsikan atau memberi gambaran terhadap situasi aktivitas pembelajaran di kelas II dalam pembelajaran berbicara melalui model pembelajaran Think Talk Write melalui data sejumlah 6 (enam) orang siswa dengan kategori siswa berkemampuan cepat berjumlah 2 (dua) orang, kategori siswa berkemampuan sedang berjumlah 2 (dua) orang, dan kategori siswa berkemampuan lambat berjumlah 2 (dua) orang.

Lokasi penelitian ini dilakukan di SDN 007 Kecamatan Sungai Pinang Kota Samarinda kelas II E yang berjumlah 27 siswa yang terdiri dari 19 siswa laki-laki dan 8 siswa perempuan. Adapun subyek penelitian ini berjumlah 6 (enam) orang siswa dengan kategori siswa berkemampuan cepat berjumlah 2 (dua) orang, kategori siswa berkemampuan sedang berjumlah 2 (dua) orang, dan kategori siswa berkemampuan lambat berjumlah 2 (dua) orang.

Adapun waktu pengambilan data dilaksanakan pada tanggal 17 Februari sampai dengan 21 Februari 2020.

Sumber data dalam penelitian menggunakan dua sumber data yaitu :

a. Sumber data primer, Sumber data primer adalah data yang langsung dikumpulkan dan diperoleh peneliti melalui pengamatan terhadap aktivitas belajar siswa di kelas.

b. Sumber data sekunder, Sumber data sekunder adalah data yang dikumpulkan melalui sumber lain melalui berbagai sumber yaitu literatur artikel, jurnal, buku yang berkenaan dengan penelitian yang dilakukan. Data sekunder ini sebagai penunjang dalam menyelesaikan permasalahan yang diteliti.

Dalam teknik pengumpulan dan perekaman data penelitian ini, peneliti menggunakan berbagai teknik yaitu observasi, wawancara dan dokumentasi. Peneliti sebagai instrumen kunci, karena dianggap orang 
yang paling mengetahui seluruh data dan cara menyikapinya. Adapun instrumen penunjang yang digunakan dalam penelitian ini adalah pedoman wawancara, pedoman observasi, dan hasil rekaman data melalui dokementasi foto.

Observasi dilakukan untuk mengamati latar (setting) kelas ketika berlangsungnya pembelajaran. Pengamatan dilakukan peneliti terhadap aktivitas di dalam kelas yang berhubungan dengan perilaku para siswa dan guru ketika pembelajaran berlangsung. Aktivitas diawali pada: (1) tahap praberbicara/think, yakni keterlibatan siswa terhadap kegiatan apersepsi, pembangkitan skemata; keseriusan siswa memperhatikan penjelasan guru tentang tujuan pembelajaran berbicara melalui metode think talk write; menyiapkan alat tulis yang diperlukan, menyimak dengan seksama saat guru memandu kegiatan membaca bersama dalam memprediksi, menyimpulkan dari buku cerita yang dibawa oleh guru. (2) tahap berbicara/talk, yakni keterlibatan siswa dalam melatih kemampuan berbicara melalui kegiatan memprediksikan buku cerita yang didemonstrasikan oleh guru melalui kegiatan mengajukan pertanyaan dengan kata tanya: apa, siapa, dimana, kapan, bagaimana untuk menggali informasi dari buku cerita yang harus diprediksikan dan disimpulkan isinya oleh siswa. (3) tahap pascaberbicara/write yakni keterlibatan siswa dalam kegiatan menuliskan tentang informasi yang diperolehnya melalui prediksi buku cerita yang didemonstrasikan oleh guru yang meliputi; apa judul cerita, dimana kejadiannya, siapa tokoh dalam cerita, kapan kejadiannya, bagaimana perasaan tokoh dalam cerita tersebut, apa isi/kesimpulan dari cerita tersebut.

Analisis data dalam penelitian ini menggunakan teknik triangulasi yang dilakukan pada saat pengumpulan data berlangsung dan setelah selesai pengumpulan data dalam periode tertentu. Menurut Milles dan Huberman (dalam Okyriana : 2015) bahwa langkah-langkah analisis data meliputi: (1) mereduksi data, (2) menyajikan data, dan (3) menyimpulkan data. Analisis data dapat dilakukan dengan menggunakan teknik data kualitatif, baik yang bersifat linier (mengalir) maupun yang bersifat sirkuler. Secara garis besar mencakup langkah-langkah sebagai berikut: (1) menelaah data terkumpul, (2) mereduksi data, (3) menyimpulkan, dan (4) verifikasi.

Menelaah seluruh data yang telah dikumpulkan. Artinya semua aktivitas siswa dalam pembelajaran berbicara melalui model pembelajaran think talk write. Proses analisis data dilakukan sejak kegiatan observasi dan pengumpulan data dilaksanaka. Misalnya data aktivitas siswa pada setiap pertemuan dikelompokkan untuk memudahkan peneliti dalam melakukan analisis berikutnya.

Mereduksi data adalah kegiatan yang didalamnya telah melibatkan pengkategorian dan pengklasifikasian. Pada tahap ini, peneliti melakukan reduksi dari berbagai sumber misalnya data hasil pengamatan berupa data perilaku empirik dan data hasil pekerjaan siswa berupa jawaban, data diperoleh dari hasil wawancara, perekaman, observasi, dan catatan lapangan. Setelah data terkumpul kemudian dilakukan klasifikasi dengan cara menyeleksi data yang relevan dengan fokus penelitian untuk kemudian dimaknai dan dijadikan dasar untuk mengambil kesimpulan. Data yang tidak berhubungan dengan fokus penelitian dibuang.

Dari kegiatan reduksi selanjutnya dilakukan kegiatan penyimpulan akhir yang selanjutnya diikuti dengan kegiatan verifikasi atau pengujian. Artinya data yang sudah lengkap akan dilakukan penafsiran data dan penarikan kesimpulan. Kemudian dilakukan kegiatan verifikasi untuk menguji temuan data penelitian tersebut.

\section{HASIL PENELITIAN}

a. Analisis Hasil Observasi Penelitian

Dalam penelitian ini, peneliti sekaligus guru dibantu satu orang guru partner sebagai observer ingin menganalisis kemampuan berbicara siswa kelas II E dengan menggunakan model pembelajaran think talk write melalui kegiatan memprediksi buku cerita yang berjudul "Molly Si Orang Utan". 
Adapun data hasil observasi yang telah dikakukan:

Tabel 4.1 Hasil penelitian Hari Pertama

\begin{tabular}{|c|c|c|c|c|}
\hline $\begin{array}{c}\text { Aspek } \\
\text { yang } \\
\text { diamati }\end{array}$ & $\begin{array}{c}\text { Lambat } \\
\mathbf{1}\end{array}$ & $\begin{array}{c}\text { Sedang } \\
\mathbf{2}\end{array}$ & $\begin{array}{c}\text { Cepat } \\
\mathbf{3}\end{array}$ & $\begin{array}{c}\text { Sangat } \\
\text { cepat 4 }\end{array}$ \\
\hline $\begin{array}{c}\text { Perhatian } \\
\text { siswa }\end{array}$ & 6 & 12 & 9 & 0 \\
\hline $\begin{array}{c}\text { Respon } \\
\text { siswa }\end{array}$ & 10 & 7 & 10 & 0 \\
\hline $\begin{array}{c}\text { Aspek } \\
\text { berpikir } \\
\text { siswa } \\
\text { think) }\end{array}$ & 12 & 9 & 6 & 0 \\
\hline $\begin{array}{c}\text { Aspek } \\
\text { berbicara } \\
\text { siswa } \\
\text { talk) }\end{array}$ & 6 & 15 & 6 & 0 \\
\hline $\begin{array}{c}\text { Taraf } \\
\text { menulis } \\
\text { (write) }\end{array}$ & 5 & 15 & 7 & 0 \\
\hline
\end{tabular}

Sumber: Hasil penelitan, 2020.

Hasil penelitian pada hari pertama sebagai observasi awal untuk pengambilan subjek penelitian melalui beberapa tahap (syntact think talk write) yakni:

a. Guru membagikan teks bacaan berupa lembar aktivitas siswa yang memuat permasalahan dan petunjuk pelaksanaan.

Berdasarkan hasil pengamatan pada kegiatan pembelajaran hari pertama diperoleh hasil pengamatan, siswa terlihat semangat dan antusias untuk mengikuti rangkaian kegiatan pembelajaran memprediksi buku "Molly Si Orang Utan", guru sesekali memberikan selingan ice breaking untuk tetap menjaga kestabilan semangat siswa dalam mengikuti proses pembelajaran.

Guru berkeliling untuk memantau kegiatan pembelajaran sekaligus sebagai pengarah kegiatan agar berjalan sesuai harapan. Pada pengamatan hari pertama observasi ditujukan kepada semua siswa, karena guru harus mendapatkan hasil dari pembelajaran pertama untuk menentukan subjek penelitian. Penentuan subjek berdasarkan hasil pengamatan dan hasil lembar aktivitas siswa untuk diklasifikasikan sesuai kategori masing-masing dan akan ditindaklanjuti pada pembelajaran kedua.

Langkah awal pembelajaran difokuskan pada perahatian siswa dan seberapa baik siswa memperhatikan penjelasan guru pada saat menyampaikan petunjuk mengejakan lembar aktivitas siswa (LAS) pada observasi awal ini terdapat 27 siswa di dalam kelas pada tabel 4.1 terlihat jelas pada indicator perhatian siswa dimana 6 orang siswa perhatian siswa masuk dalam kategori lambat, 12 orang siswa masuk dalam kategori sedang dan 6 orang siswa masuk dalam kategori cepat sementara sangat cepat tidak ada, berdasarkan hasil penelitian hari pertama menunjukan ada permasalahn terkait perhatian siswa yang disebabkan siswa kurang fokus dan lebih banyak bermain dengan teman-teman disekitarnya.

Hasil penelitian diatas sejalan dengan penelitian yang dilakukan oleh Samul, 2018 menyatakan bahwa kemampuan berbicara siswa kelas awal pada indicator "perhatian siswa" masih sangat lambat karena fokus untuk siswa kelas awal masih sangat kurang hal tersebut disebabkan siswa asyik bermain dengan teman sebangku. Hal itu dapat diatasi dengan memperbanyak ice breaking dan memberikan lembar aktivitas siswa yang menarik sehingga kelas lebih tenang dan tujuan pembelajaran tercapai secara optimal.

\section{b. Siswa membaca teks dan membuat catatan hasil bacaan secara individual (think)}

Siswa memulai melaksanakan pembelajaran dengan mengamati gambar yang ada di lembar aktivitas siswa, seraya berpikir apa kira-kira isi buku cerita "Molly $\mathrm{Si}$ Orang Utan" ini. Berdasarkan pengamatan yang peneliti lakukan, siswa terlihat diam dan berpikir, walau masih ada beberapa siswa yang kurang antusias hal ini dikarenakan ada beberapa siswa yang belum lancar membaca sehingga mereka kurang memahami bagaimana cara mengerjakan lembar aktivitas yang diberikan. Guru segera berinisiatif untuk mendekati siswa yang kurang antusias tersebut dengan membimbingnya dan tetap memberikan semangat.

Berdasarkan hasil penelitian yang telah dilakukan terlihat pada tabel 4.1 dimana respon siswa berada pada kategori lambar 10 orang, 7 orang pada kategori sedang dan 10 siswa berada pada kategori cepat sementara pada aspek berpikir siswa 12 orang siswa pada kategori lambat, 9 orang siswa pada kategori sedang dan 6 pada kategori cepat, 
jika dilihat dari data tersebut 2 indikator kemampuan berbicara siswa masih perlu ditingkatkan dengan beberapa metode dan pendekatan serta perhatian khusus dari guru kelas. Sejalan dengan hasil penelitian yang telah dilakukan oleh Irene Fitriana Wahyuni dkk, 2017 menyatakan bahwa untuk meningkatkan kemampuan berbbicara siswa diperlukan inovasi dan model pembelajaran talk and write karena relevan dengan sintaks pembelajaran dan memprediksi buku salah satu metode yang relevan sehingga siswa mengalamipeningkatan pada aspek intonasi, kelancaran, dan kejelasan isi cerita.

\section{c. Siswa berinteraksi dengan teman satu kelompok untuk membahas isi catatan (talk)}

Siswa mulai berinteraksi dan berdiskusi bersama teman kelompoknya untuk mendiskusikan apa isi buku cerita "Molly Si Orang Utan“ Hasil pengamatan diperoleh gambaran kegiatan siswa saat berdiskusi, mereka terlihat berbincang-bincang dengan teman sekelompoknya. Aspek berbicara salah satu indikator yang sangat penting untuk melihat tingkat kemampuan berbicara siswa sejalan dengan penelitian yang dilakukan oleh Zainudin, 2017 dengan hasil penelitian bahwa memprediksi isi buku dan menggunakan model pembelajaran talk and write mampu meningkatkan kemampuan berbicara siswa dan memberikan motivasi kepada siswa kelas awal untuk selalu aktif pada saat pembelajaran dan aktif memberikan pertanyaan, proses pembelajaran yang menggunakan model talk and write memberikan pengaruh positif bagi siswa kelas awal.

\section{d. Siswa menkonstruksi sendiri pengetahuan yang didapatkan dari hasil diskusi (write)}

Setelah melalui diskusi dalam kelompok masing-masing, guru memberikan instruksi agar siswa menuliskan hasil diskusinya berdasarkan kesimpulan dan bahasa masing-masing. Berdasarkan hasil pengamatan, siswa terlihat mulai menulis dilembar aktivitas siswa. Tampak beberapa siswa yang masih diam dan hanya melihat lembar aktivitasnya karena mereka mengalami kesulitan untuk memahami petunjuk dalam lember tersebut karena belum lancar membaca. Guru segera mendekati siswa yang mengalami kesulitan dan membimbingnya untuk mengerjakan tugasnya. Pada proses ini focus pengamatan pada kemampuan siswa menulis yang sifatnya berkelanjutan sehingga pembelajarannya pun perlu dilakukan secara berkesinambungan sejak sekolah dasar. Hal ini didasarkan pada pemikiran bahwa menulis merupakan kemampuan dasar sebagai bekal belajar menulis di jenjang berikutnya. Oleh karena itu, pembelajaran menulis di sekolah dasar perlu mendapat perhatian yang optimal sehingga dapat memenuhi target kemampuan menulis yang diharapkan.

Sejalan dengan penelitian yang telah dilakukan oleh Sabarti, 1992 yang menyatakan bahwa bahwa anak-anak berpengetahuan awal tentang tulisan. Mereka memiliki kecenderungan melihat mereka sendiri sebagai penulis. Dalam hal ini mereka dengan cepat mempelajari konvensi bahasa tulis. Anak kelas satu ingin menulis, menulis, dan menulis lagi. Kegiatan menulis tampaknya mengalir dari hasil yang tampa kualitas dan setelah draft pertama ditulis, beberapa anak cemas untuk memulai lagi. Dalam masa menulis biasanya bagi pemula menulis tiga atau empat baris. Anak-anak kelas satu mempunyai keinginan untuk menuliskan idenya pada lembaran kertas dan mengeluarkan pendapatnya yang masih ada di otak mereka. (Azlia Latae. 2019)

\section{e. Mempresentasikan hasil diskusi kelompoknya}

Setelah siswa selesai menuliskan hasil diskusinya, guru meminta perwakilan kelompok untuk mempresentasikan kedepan secara bergantian. Pada saat perwakilan kelompok lain mempresentasikan di depan, kelompok lain menyimak dengan tenang. Kegiatan presentasi yang dilakukan oleh perwakilan masing-masing kelompok peneliti akan focus pada kemampuan (Berbicara) didepan kelas dan susunan kalimat yang disusun oleh kelompok masing-masing. Kemampuan berbicara siswa yang dinilai berdasarkan hasil kerja kelompok yang presentasikan oleh perwakilan kelompok masing-masing terlihat jelas bahwa kemampuan berbicara siswa berada pada kategori lambat 5 orang, kategori sedang 15 
orang dan 7 orang pada kategori cepat. Berdasarkan hasil pengamatan hari pertama kemampuan berbicara siswa perlu ditingkatkan dengan mengulang pembelajaran menggunakan model talk and write pada materi berikutnya, untuk aktivitas presentasi siswa dapat dilihat pada gambar di bawah ini.

\section{f. Guru bersama siswa melakukan refleksi dan membuat kesimpulan dari permasalahan yang diberikan.}

Setelah semua perwakilan kelompok mempresentasikan ke depan, guru meminta siswa untuk mengumpulkan lembar aktivitas siswa untuk dikoreksi dan menjadi acuan untuk menentukan subjek penelitian serta ditambah dengan hasil pengamatan selama proses belajar berlangsung. Kegiatan selanjutnya guru bersama siswa melakukan refleksi dan konfirmasi dengan membaca buku "Molly Si Orang Utan". Sehingga siswa akan mengetahui isi buku yang sebenarnya. Guru menyampaikan bahwa jawaban tidak benar atau salah akan tetapi lebih ditujukan kepada sikap siswa, keterampilan siswa dalam mengikuti proses pembelajaran model think talk write ini. Guru bertanya kepada siswa tentang bagaimana perasaannya dengan pembelajaran, apa yang menjadi kesulitannya, bagaimana cara mengatasinya dan tidak lupa guru memberikan motivasi agar siswa tetap semangat dalam belajar. Guru juga menyampaikan tindak lanjut untuk pembelajaran berikutnya yaitu memprediksi buku "Pesut Mahakam".

\section{b. Analisis Hasil Observasi Aktivitas Belajar Siswa Hari Ke-2 sampai hari ke-4}

Setelah penentuan subjek penelitian pembelajaran model think talk write dengan aktivitas siswa memprediksi isi buku cerita, maka untuk data dan hasil penelitian hari ke2 sampai hari ke-4 akan direduksi untuk menarik kesimpulan dan menemukan solusi untuk permasalahan yang terjadi berikut data (Hasil observasi, Nilai Test Siswa, Penilaian wawancara, dan Penilaian hasil presentasi siswa)

Display data pada diagram batang berikutnya berkaitan dengan hasil analsisi data wawancara dan hasil presentasi siswa yakni:

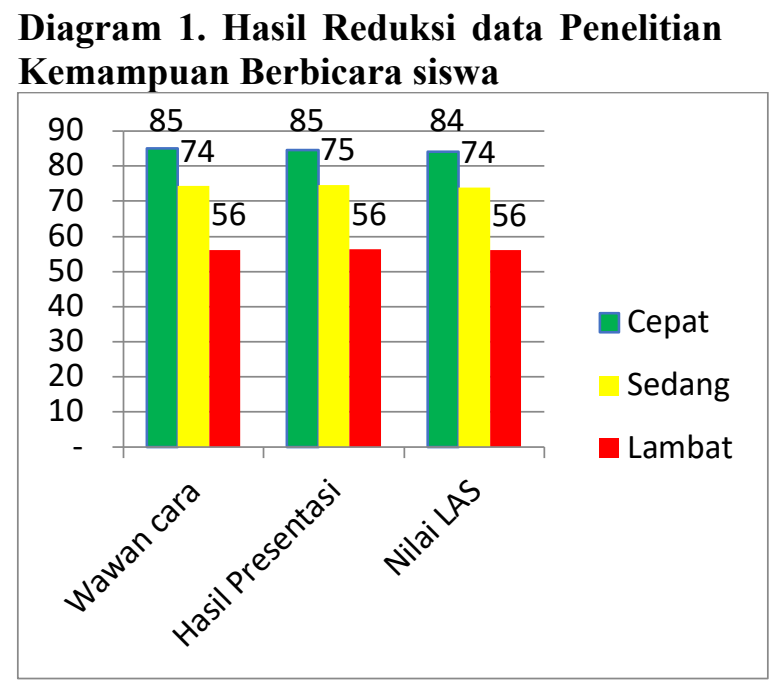

Berdasarkan tabel dan Diagram diatas maka hasil penelitian akan dijabarkan sesuai dengan langkah-langkah pembelajaran think talk write yakni:

\section{a. Fokus Perhatian siswa}

Sebagaimana hari pertama, kegiatannya adalah memprediksi buku, guru menjelaskan langkah-langkah pembelajaran sambil memberikan motivasi kepada siswa dengan memberikan selingan ice breaking untuk membangkitkan semangat siswa dalam melaksanakan pembelajaran. Setelah siswa memahami petunjuk pelaksanaan guru membagikan lembar aktivitas,kepada seluruh siswa. Sehingga yang manjadi focus pada kegiatan pertama ini adalah kemampuan siswa memperhatikan dan seberapa baik siswa memperhatikan penjelasan guru pada saat menyampaikan petunjuk mengejakan lembar aktivitas siswa (LAS) pada diagram.

Analisis data kemampuan siswa memperhatikan dideskripsikan melalui hasil wawancara yang ditekankan pada aspek kemampuan siswa memahami penjelasan guru dan hasi presentasi siswa. Kemampuan 6 orang siswa yang menjadi objek penelitian memhami penjelasan siswa berada pada kategori cepat yang disimpulkan dari hasil wawancara, presentasi dan Nilai LAS siswa. Hal tersebut sejalan dengan penelitian yang telah dilakukan oleh Hapna, 2014 yang menyatakan bahwa kegiatan presentasi hasil kerja kelompok mencapai kesempurnaan, yaitu $100 \%$ selama 3 hari penelitian, dibandikngkan pada kegiatan observasi 
hanya mencapai $80 \%$. Dengan demikian, melalui pembelajaran aspek berbicara, siswa membangun dan menemukan pengetahuan sendiri. Siswa juga dapat melaksanakan dan menyelesaikan tugas yang diberikan guru. Dalam hal ini, guru hanya sebagai fasilitator.

Dalam pembelajaran presentasi tugas mandiri dengan power point dalam diskusi kelompok, proses belajar mengajar lebih aktif, kreatif, efektif, dan menyenangkan.

\section{b. Siswa berpikir (think)}

Berdasarkan hasil dokumentasi dan triangulasi pengumpulan data observasi dan wawancara selama proses pembelajaran berlangsung siswa yang menjadi subjek penelitian, analisis data kemampuan berpikir siswa yang menjadi subjek penelitian kemampuan berpikir siswa dapat disimpulkan dari hasil wawancara, presentasi dan nilai LAS siswa hanya satu orang siswa yang berada pada kategori lambat dan dua orang berada pada kategori sedang. Berdasarkan hasil temuan penelitian tersebut dapat disimpulkan bahwa melalui pembelajaran model think talk write memiliki dampak positif bagi perkembangan berpikir siswa. Dimana dari hasil awal dilakukan observasi terhadap subjek penelitian mengalami peningkatan kemampuan di hari kedua sampai hari keempat dilaksanakan penelitian.

Analisis data kemampuan berpikir siswa dideskripsikan melalui hasil wawancara yang ditekankan pada aspek kemampuan siswa mempresentasikan hasil kelompok. Kemampuan 6 orang siswa yang menjadi objek penelitian kemampuan berpikir siswa berada pada kategori cepat yang disimpulkan dari hasil wawancara, presentasi dan Nilai LAS siswa hanya satu orang siswa yang berada pada kategori lambat dan sedang dan empat siswa kategori cepat.

Hasil ini sejalan dengan Ratna Purwati, 2018 menyatakan bahwa siswa dengan kemampuan brpikir cepat mampu memenuhi kriteria semua indikator berpikir kritis yang digunakan dalam penelitian ini yaitu menginterpretasi masalah, menganalisis, mengevaluasi, dan mengiferensi. Siswa dengan kemampuan berpikir sedang hanya mampu memenuhi indikator interpretasi dan menganalisis namun kurang mampu dalam memenuhi indikator mengevaluasi dan menginferensi. Sedangkan, siswa dengan kemampuan berpikir kritis rendah kurang mampu memenuhi indikator interpretasi karena siswa hanya mampu mengidentifikasi fakta yang diberikan dengan jelas pada soal serta tidak mampu memenuhi indikator menganalisis, mengevaluasi serta menginferensi.

\section{c. Siswa melakukan diskusi (talk)}

Hasil pengamatan terhadap subjek penelitian diperoleh gambaran bahwa siswa dengan kategori cepat terlihat berdiskusi aktif dalam kelompoknya. Sedangkan siswa dengan kategori sedang terlihat sesekali menyampaikan gagasannya dalam kelompoknya, adapun siswa dengan kategori lambat terlihat diam dan memegang lembar aktivitasnya tanpa mengatakan apa-apa. Pada proses talk peneliti akan fokus pada indikator kemampuan siswa berbicara atau menyampaikan informasi kepada temanteman kelompok dan informasi tersebut dapat diterima oleh pendengar, kegiatan talk ini lebih ditekankan pada bagaimana kemampuan siswa dalam membahas catatancatatan yang ditulis pada saat diskusi kelompok dan bagaimana sikap siswa kepada teman sejawat.

Adanya komunikasi dengan teman sejawat akan membangun pengetahuan dan memberikan pembelajaran kepada siswa bahwa pentingnya meningkatkan kemampuan komunikasi hal ini sejalan dengan Hal Zahorik (Depdiknas, 2004) yang menyatakan bahwa pengetahuan dibangun oleh manusia sedikit demi sedikit, yang hasilnya diperluas melalui konteks yang terbatas (sempit) dan tidak sekonyongkonyong. Pengetahuan bukanlah seperangkat fakta-fakta, konsep, atau kaidah yang siap untuk diambil dan diingat. Manusia harus mengkonstruksi pengetahuan itu dan memberi makna melalui pengalaman nyata. Siswa perlu dibiasakan untuk memecahkan masalah, menemukan sesuatu yang berguna bagi dirinya, dan bergelut dengan ide-ide. Esensi dari teori konstruktivistik adalah ide bahwa siswa harus menemukan dan mentransformasikan suatu informasi kompleks ke situasi lain, dan 
apabila dikehendaki, informasi itu menjadi milik mereka sendiri.

\section{d. Siswa menulis (write).}

Setelah melalui diskusi dalam kelompok masing-masing, guru memberikan instruksi agar siswa menuliskan hasil diskusinya berdasarkan kesimpulan dan bahasa masing-masing. Berdasarkan hasil pengamatan, siswa dengan kategori berkemampuan cepat langsung menuliskan hasil pemikirannya dengan tulisan yang rapi. Siswa dengan kategori berkemampuan sedang terlihat diam sejenak kemudian mulai menulis dilembar aktivitas siswa.

Kemampuan 6 orang siswa yang menjadi objek penelitian kemampuan menulis siswa berada pada kategori cepat yang disimpulkan dari hasil wawancara, presentasi dan Nilai LAS siswa hanya satu orang siswa yang berada pada kategori lambat dan hal tersebut diakibatkan karena faktor yang tidak berkaitan dengan lingkungan belajar. Kemampuan menulis siswa menentukan bahwa kemampuan merangkai kalimat siswa telah mencapai kategori cepat, selama proses penelitian yang telah dilakukan dengan menggunakan model talk and write menunjukan bahwa kemampuan berbicara siswa yang dinilai melalui menulis sangat cepat, hal ini sejalan dengan hasil penelitian yang dilakukan oleh Gudu, 2015 menyatakan bahwa model pembelajaran talk and write sangat relevan dengan meningkatkan kemampuan menulis siswa kelas awal.

\section{e. Siswa mempresentasikan hasil diskusi kelompoknya}

Setelah siswa selesai menuliskan hasil diskusinya, guru meminta siswa yang menjadi subjek penelitian untuk maju ke depan mempresentasikan hasil tugas yang diberikan. Siswa dengan kategori cepat maju ke depan dengan percaya diri dan suara yang lantang membacakan hasil pekerjaanya. Siswa dengan kategori sedang mempresentasikan ke depan dengan suara yang kurang jelas, dan siswa dengan kategori berkemampuan lambat dengan malu-malu meju ke depan dan membaca hasil pekerjaannya dengan bacaan yang terputus-putus karena kurang lancar dlam membaca, sehingga kurang bisa dipahami. Pada tahap ini peneliti focus pada indicator kemampuan berbicara yang terbagi menjadi beberapa indicator yaitu (Tata Bahasa, Kosa kata, Kelancaran, Kenyaringan dan gerak mimik) berikut data yang telah direduksi berdasarjan hasil presentasi lembar aktivitas siswa.

\section{Diagram 2. Data Hasil Penilaian Presentasi Lembar Aktivitas Siswa}

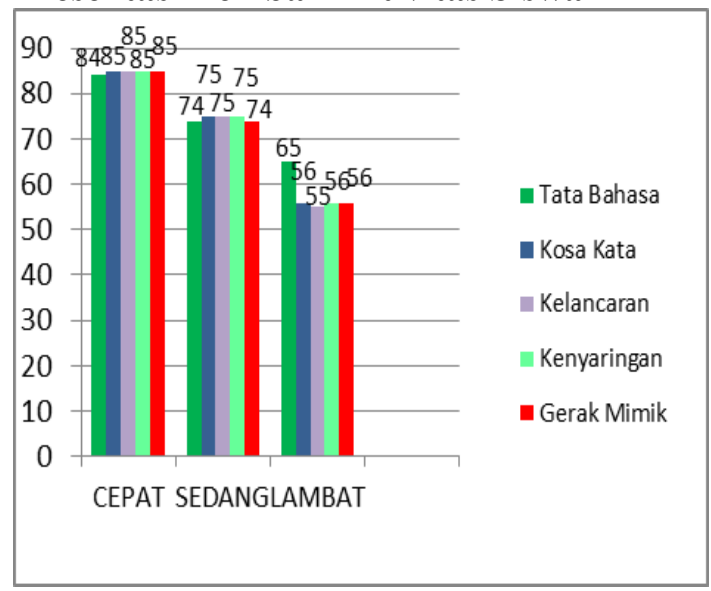

\section{a. Aspek Tata Bahasa}

Dari hasil penelitian, dapat disimpulkan bahwa siswa dengan kategori berkemampuan cepat sangat bagus dalam tata bahasa kalimat. Siswa sangat lancar dalam menyampaikan ide, gagasan saat berdiskusi, presentasi maupun pada saat wawancara dengan rentang nilai. Siswa dengan kategori berkemampuan sedang cukup bagus dalam tata kalimatnya. Terdapat beberapa kesalahan akan tetapi tidak mengganggu komunikasi dan maksud kalimatnya masih bisa dipahami dengan rentang nilai. Sedangkan siswa dengan kategori berkemampuan lambat banyak terdapat kesalahan dalam tata kalimat sehingga mengganggu komunikasi dan makna dari pembicaraannya kurang bisa dipahami dengan rentang nilai.

\section{b. Kosakata (pilihan kata)}

Berdasarkan hasil penelitian, dapat disimpulkan bahwa siswa dengan kategori berkemampuan cepat sangat bagus dalam pemilihan kata. Pemilihan kata sudah luas dan sesuai dengan situasi pembicaraan, hanya terdapat sedikit kesalahan yaitu ketelitian dan kecermatan dalam pemilihan kata. Pemilihan kata pada siswa dengan kategori berkemampuan sedang masih 
terbatas, sehingga pembicaraan masih terbatas pada kosakata sederhana yang dikuasai. Siswa dengan kategori berkemampuan lambat masih sangat terbatas dalam pemilihan kosakata, siswa cenderung pendiam dan lambat dalam mengeluarkan suara.

\section{c. Kelancaran}

Berdasarkan hasil penelitian, dapat disimpulkan bahwa siswa dengan kategori berkemampuan cepat cukup lancar dalam berkomunikasi. Siswa terlihat percaya diri dan tidak banyak jeda, hanya kadangkadang tampak ragu pada saat berbicara, tapi secara umum siswa lancar dalam berkomunikasi. Bagi siswa dengan kategori berkemampuan sedang secara umum lancar, tapi pembicaraan sering nampak ragu dan kadang-kadang kalimat tidak lengkap pada saat berbicara. Siswa dengan kategori berkemampuan lambat terlihat lambat dalam berbicara. Siswa terlihat sulit untuk mengeluarkan suara kecuali untuk kalimat yang pendek dan yang bersifat rutinitas.

\section{d. Kenyaringan suara}

Berdasarkan hasil penelitian yang dilakukan, kemampuan siswa dalam aspek kenyaringan suara bagi siswa berkemampuan cepat suara sangat jelas terdengar dan mudah dipahami maksud dan tujuannya.Siswa dengan kategori kemampuan sedang, suara keras tapi nadanya terkesan datar sehingga kurang jelas maksudnya. Terkadang juga suara pelan dan kurang jelas untuk didengar.Suara terdengar sangat pelan sehingga kurang jelas terdengar dan akibatnya sulit dipahami maksud dan tujuan pembicaraannya.

\section{e. Gerak mimik (ekspresi)}

Siswa dengan kategori berkemampuan cepat memiliki ekspresi yang sesuai dengan situasi dan terkadang ditambah dengan gerakan tangan untuk memberikan ketegasan. Berdasarkan hasil penelitian, siswa berkemampuan sedang memiliki gerak mimik yang bagus hanya tidak ditambah dengan gerakan tangan atau tubuh lain untuk menambah penegasan. Gerak mimik cenderung datar dan kurang ekspresif, sehingga kurang sesuai dengan pernyataan yang disampaikan.

\section{f. Guru bersama siswa melakukan refleksi dan membuat kesimpulan dari permasalahan yang diberikan.}

Setelah semua siswa yang menjadi subjek penelitian mempresentasikan ke depan, guru bersama siswa melakukan refleksi dan menkonfirmasi isi buku cerita "Pesut Mahakam" serta membuat kesimpulan dari pembelajaran yang dilakukan. Guru bertanya kepada siswa tentang bagaimana perasaannya dengan pembelajaran, apa yang menjadi kesulitannya, bagaimana cara mengatasinya dan tidak lupa guru memberikan motivasi agar siswa tetap semangat dalam belajar. Guru juga menyampaikan tindak lanjut untuk pembelajaran berikutnya. Berikut tabel hasil observasi terhadap kegiatan pembelajaran siswa

\section{B. Analisis Hasil Wawancara}

Wawancara dilaksanakan oleh peneliti guna memperoleh informasi tentang kemampuan berbicara siswa. Kegiatan wawancara dilaksanakan pada hari Jumat, 21 Februari 2020. Peneliti dibantu guru partner untuk memantau siswa sementara peneliti yang sekaligus guru memanggil siswa sebagai subjek penelitian secara bergantian. Isi wawancara adalah terkait respons siswa terhadap proses pembelajaran model think talk write melalui kegiatan memprediksi buku cerita. Hasil wawancara ini untuk mengetahui kemampuan berbicara siswa dengan memperhatikan aspek: Tekanan, Tata bahasa, Kosakata (pilihan kata), Kelancaran, Pemahaman.

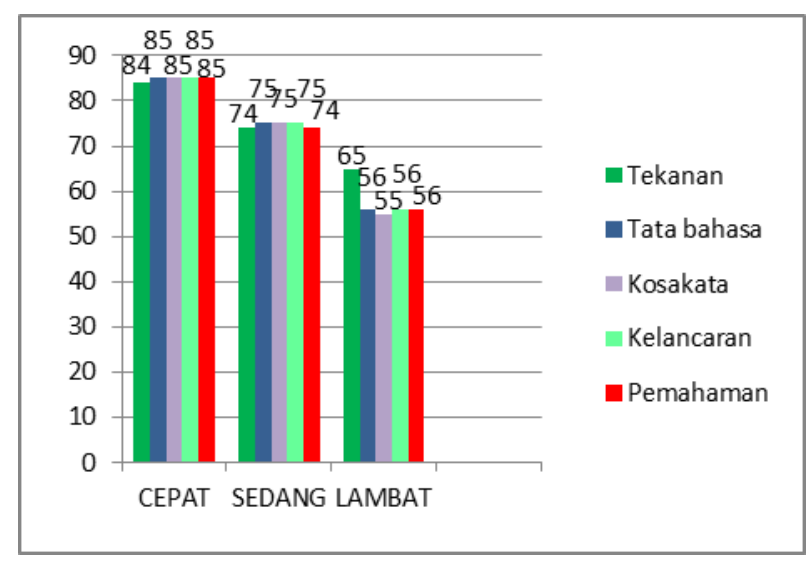


a. Tekanan

Berdasarkan pengamatan yang dilakukan, siswa dengan kategori berkemampuan cepat mendekati ucapan standard dan tidak banyak kesalahan dalam mengucapkan sehingga pembicaraannya bisa dipahami maksudnya. Siswa dengan kategori kemampuan sedang terkadang ada pengaruh bahasa daerah sehingga pembicaraan agak sulit dipahami maksudnya. Hasil pengamatan menunjukkan bahwa siswa berkemampuan lambat memiliki aksen yang kuat dan sering terjadi kesalahan sehingga untuk bisa dimengerti harus mengulang kembali pembicaraannya.

\section{b. Tata bahasa kalimat}

Dari hasil penelitian, dapat disimpulkan bahwa siswa dengan kategori berkemampuan cepat sangat bagus dalam tata bahasa kalimat. Siswa sangat lancar dalam menyampaikan ide, gagagasan saat berdiskusi,presentasi maupun pada saat wawancara.

Berdasarkan hasil penelitian, peneliti memperoleh hasil bahwa siswa dengan kategori kemampuan sedang cukup bagus dalam tata kalimatnya. Terdapat beberapa kesalahan akan tetapi tidak mengganggu komunikasi dan maksud kalimatnya masih bisa dipahami.

Tata bahasa kalimat pada siswa dengan kategori berkemampuan lambat diperoleh hasil bahwa banyak terdapat kesalahan dalam tata kalimat sehingga mengganggu komunikasi dan makna dari pembicaraannya kurang bisa dipahami.

\section{c. Kosakata (pilihan kata)}

Berdasarkan hasil penelitian, dapat disimpulkan bahwa siswa dengan kategori berkemampuan cepat sangat bagus dalam pemilihan kata. Pemilihan kata sudah luas dan sesuai dengan situasi pembicaraan, hanya terdapat sedikit kesalahan yaitu ketelitian dan kecermatan dalam pemilihan kata. Pemilihan kata pada siswa dengan kategori berkemampuan sedang masih terbatas, sehingga pembicaraan masih terbatas pada kosakata sederhana yang dikuasai. Siswa dengan kategori berkemampuan lambat masih sangat terbatas dalam pemilihan kosakata, siswa cenderung pendiam dan lambat dalam mengeluarkan suara.

\section{d. Kelancaran}

Berdasarkan hasil penelitian, dapat disimpulkan bahwa siswa dengan kategori berkemampuan cepat cukup lancar dalam berkomunikasi. Siswa terlihat percaya diri dan tidak banyak jeda, hanya kadangkadang tampak ragu pada saat berbicara, tapi secara umum siswa lancar dalam berkomunikasi. Bagi siswa dengan kategori berkemampuan sedang secara umum lancar, tapi pembicaraan sering nampak ragu dan kadang-kadang kalimat tidak lengkap pada saat berbicara. Siswa dengan kategori berkemampuan lambat terlihat lambat dalam berbicara. Siswa terlihat sulit untuk mengeluarkan suara kecuali untuk kalimat yang pendek dan yang bersifat rutinitas.

\section{e. Pemahaman}

Berdasarkan hasil penelitian yang dilakukan, kemampuan siswa dalam aspek pemahaman sangat memahami segala sesuatu dalam percakapan formal. Sehingga ketika diwawancarai tidak mengalami kesulitan. Siswa dengan kategori kemampuan sedang, memiliki pemahaman dalam percakapan sederhana dan dalam hal tertentu perlu adanya pengulangan dan penjelasan. Memiliki kemampuan pemahaman yang lambat dan perlu diberikan penjelasan yang sangat mendalam agar siswa memahami maksud dan tujuan pembicaraan yang dilakukan.

\section{Dokumentasi Proses Pembelajaran}

Dokumentasi foto merupakan data yang cukup penting sebagai bukti terjadinya suatu peristiwa. Dalam penelitian ini, peneliti memandang perlu menggunakan dokumentasi foto sebagai salah satu data instrumen non test. Penggunaan instrumen berupa pengambilan gambar (foto) ini dimaksudkan untuk memperoleh rekaman aktivitas atau perilaku siswa selama mengikuti proses pembelajaran dalam bentuk dokumentasi gambar. Dokumentasi foto akan memperkuat bukti analisis, data yang diambil melalui dokumentasi foto ini juga memperjelas data yang lain yang hanya mendeskripsikan melalui tulisan atau angka. Sebagai alat penelitian, hasil dokumentasi gambar (foto) ini selanjutnya dideskripsikan sesuai keadaan yang ada serta dipadukan dengan data-data yang lain. Berikut peneliti 
tampilkan beberapa dokumentasi yang diambil pada saat proses belajar berlangsung, yang menggambarkan situasi pada saat pembelajaran dilakukan.

\section{Pembahasan}

Pembahasan temuan hasil penelitian ini akan mendeskripsikan hasil penelitian untuk mengungkapkan hasil analisis kemampuan berbicara dengan model think talk write melalui kegiatan menprediksi buku cerita dengan subjek 6 orang siswa dengan kriteria; 2 orang siswa kategori kemampuan cepat, 2 orang siswa kategori kemampuan sedang dan 2 orang siswa dengan kategori kemampuan lambat. Dengan tahapan think talk write yang memiliki tahapan atau sintaks sebagai berikut:

Perhatian siswa, Berdasarkan hasil pengamatan selama proses pembelajaran berlangsung siswa yang menjadi subjek penelitian baik siswa yang berkemampuan cepat, sedang maupun lambat terlihat antusias untuk mengikuti pembelajaran. Hal ini dikarenakan guru selalu memberikan motivasi dan selingan pembelajaran berupa ice breaking sehingga siswa semangat mengikuti pembelajaran memprediksi buku cerita "Molly Si Orang Utan" dan Pesut Mahakam"

Kemampuan siswa berpikir, Berdasarkan hasil pengamatan dipaparkan bahwa pada tahap ini siswa terlihat diam dan berpikir untuk memulai memprediksi buku cerita yang ada di lembar aktivitas siswa. Sejalan dengan para ahli konstruktivisme tentang landasan berpikir (filosofi) pendekatan CTL, yaitu bahwa pengetahuan dibangun oleh manusia sedikit demi sedikit, yang hasilnya diperluas melalui konteks yang terbatas, dan tidak serta merta. Pengetahuan bukanlah seperangkat fakta-fakta, konsep, atau kaidah yang siap untuk diambil dan diingat. Manusia harus mengkonstruksi pengetahuan itu dan memberi makna melalui pengalaman nyata. Esensi dari teori konstruktivis adalah ide bahwa siswa harus menemukan dan mentransformasikan suatu informasi kompleks ke situasi lain, dan apabila dikehendaki informasi itu menjadi milik mereka sendiri. Dengan dasar itu, pembelajaran harus dikemas menjadi proses mengkonstruksi bukan menerima pengetahuan. Dalam proses pembelajaran, siswa membangun sendiri pengetahuan mereka melalui keterlibatan aktif dalam proses belajar dan mengajar. Siswa menjadi pusat kegiatan, bukan guru. (Mulyani Sumantri, 2014: 1.45).

\section{Kemampuan siswa berbicara (talk)}

Berdasarkan hasil dokumentasi dan triangulasi pengumpulan data observasi dan wawancara selama proses pembelajaran berlangsung siswa yang menjadi subjek penelitian, analisis data kemampuan berbicara siswa melalui wawancara yang telah dilakukan bahwa pada tahap ini siswa dilatih untuk mengembangkan kemampuan berbicara dengan menyampaikan ide, gagasan, pertanyaan, perasaan melalui bahasa lisan baik dengan teman dalam kelompoknya maupun dengan guru. Dari hasil temuan penelitian dapat disimpulkan bahwa melalui model pembelajaran think talk write dapat meningkatkan kemampuan berbicara siswa kelas awal sebagaimana yang sudah diuraikan pada paparan data temuan hasil penelitian bahwa hanya terdapat satu siswa yang dengan kategori lambat dan sedang sedangkan empat siswa lainnya dengan kategori cepat.

Jean Piaget (dalam Mulyani Sumantri, 2014: 1.44) dalam teori perkembangan kognitif mempunyai pengaruh besar untuk memahami bagaimana anak memperoleh dan menggunakan pengetahuan. Pengetahuan anak terbentuk secara berangsur sejalan dengan pengalaman yang berkekesinambungan dan bertambah luasnya pemahaman tentang informasi-informasi yang ditemui. Anak menjalani tahap-tahap perkembangan kognitif secara pasri yang mengalami peningkatan dan perkembangan dalam setiap tahapannya. Dimana kemampuan kognitif mempengaruhi kemampuan berbicara anak dalam menyampaikan ide, gagasan, perasaan melalui bahasa lisan.

\section{Kemampuan Siswa (write),}

Berdasarkan hasil dokumentasi dan triangulasi pengumpulan data observasi dan wawancara selama proses pembelajaran berlangsung siswa yang menjadi subjek penelitian, analisis data kemampuan menulis siswa melalui wawancara yang telah 
dilakukan bahwa berdasarkan hasil pengamatan, terhadap kemampuan 6 orang siswa yang menjadi subjek penelitian kemampuan menulis siswa berada pada kategori cepat yang disimpulkan dari hasil wawancara, presentasi dan Nilai LAS siswa hanya satu orang siswa yang berada pada kategori lambat . Kemampuan menulis siswa menentukan bahwa kemampuan merangkai kalimat siswa telah mencapai kategori cepat, selama proses penelitian yang telah dilakukan dengan menggunakan model think talk write menunjukan bahwa kemampuan berbicara siswa yang dinilai melalui menulis sangat cepat

Hasil analisis kemampuan siswa menulis sejalan dengan penelitian yang dilakukan oleh Rusmin Silaban, 2017 menyatakan bahwa metode latihan yang ada dalam sintaks model pembelajaran think talk and write siswa kelas I SD kemampuan siswa dalam menulis kata sederhana mengalami peningkatan. Di mana diketahui dari data awal rata-rata nilai 59,3 atau dalam kategori sedang. Jika dilihat dari ketuntasan klasikal, ada $28,6 \%$ atau 2 siswa yang tuntas memperoleh nilai sesuai standar KKM, yakni minimal 65. Namun setelah diterapkannya metode latihan, diperoleh rata-rata nilai 67,1 atau dalam kategori tinggi.

\section{Kemampuan siswa presentasi,}

Berdasarkan hasil dokumentasi dan triangulasi pengumpulan data observasi dan wawancara selama proses pembelajaran berlangsung siswa yang menjadi subjek penelitian, analisis data kemampuan mempresentasikan hasil diskusi maupun lembar aktivitas siswa terhadap kemampuan 6 orang siswa yang menjadi subjek penelitian kemampuan berbicara siswa dapat disimpulkan dari hasil wawancara, presentasi dan Nilai LAS siswa hanya satu orang siswa yang berada pada kategori lambat dan sedang dan empat orang pada kategori cepat.

Menurut Nurgiyanto (dalam Providencia, 2015) mengungkapkan bahwa berbicara adalah aktivitas berbahasa kedua yang dilakukan oleh manusia dalam kehidupannya. Keterampilan berbicara merupakan keterampilan kedua setelah keterampilan mendengarkan, berdasarkan bunyi-bunyi yang didengar itu kemudian manusia belajar untuk mengucapkan dan akhirnya terampil berbicara. Berbicara adalah suatu sistem tanda yang dapat didengar (audible) dan yang kelihatan (visible) yang memanfaatkan sejumlah otot tubuh manusia demi maksud dan tujuan gagasan atau ide-ide yang dikombinasikan dan dapat dimengerti oleh pendengar. Berikut aspek dalam kemampuan berbicara :

Aspek tata bahasa kalimat; bagi siswa dengan kategori berkemampuan cepat sedikit saja terjadi kesalahan tetapi tidak mengganggu makna presentasi dan pembicaraan yang disampaikan sehingga maksud dan tujuan pembicaraannya bisa dipahami dengan mudah. Adapun bagi siswa yang berkemampuan sedang sebagaimana yang sudah dipaparkan pada hasil temuan penelitian bahwa dalam tata bahasa siswa berkemampuan sedang beberapa kali terjadi kesalahan yang diakibatkan oleh kecerobohan dan kurang cermat dalam menyampaikan hasil presentasi atau pembicarannya yang dapat mengganggu komunikasi.

Aspek kosakata; bagi siswa dengan kategori berkemampuan cepat memiliki perbendaharaan kosakata yang luas, hanya sedikit terjadi kesalahan yang diakibatkan kegugupan atau kurang cermat saat berbicara. Secara umum mereka memiliki kosakata yang luas dan bisa menyesuaikan situasi pembicaraan. Bagi siswa dengan kategori berkemampuan sedang memiliki perbendaharaan kosakata yang luas hanya sering terjadi kesalahan karena kurang cermat dalam berbicara. Siswa membutuhkan bimbingan dan motivasi agar lebih cermat dan pemilihan kosakata dan menyesuaikan dengan situasi pembicaraan.

Aspek kelancaran; berdasarkan hasil pengamatan dan wawancara dengan subjek penelitian, siswa dengan ketegori berkemampuan cepat memiliki tingkat kelancaran yang bagus. Pembicaraan sangat lancar hanya sesekali tampak ragu yang dikarenakan rasa percaya diri atau malu. Seiring bertambahnya usia dan dengan dukungan motivasi dari lingkungan sekitarnya maka siswa akan menjadi pribadi 
yang terampil dalam berbicara di depan umum. Adapun bagi siswa dengan kategori berkemampuan sedang memiliki tingkat kelancaran yang standar. Siswa sering tampak ragu dan diam disela pembicaraan. Siswa membutuhkan stimulasi dan motivasi agar kemampuan siswa dalam berbicara bisa lebih baik. Lain halnya siswa dengan kategori berkemampuan lambat, mereka memiliki tingkat kelancaran yang rendah. Pembicaraan sangat lambat kecuali untuk kalimat yang pendek dan rutin. Siswa membutuhkan bimbingan dan latihan agar tingkat kelancaran dalam berkomunikasi mengalami peningkatan.

Aspek kenyaringan suara; berdasarkan hasil pengamatan dan wawancara yang dilakukan, dalam hal kenyaringan suara siswa memiliki tingkat kenyaringan yang berbeda-beda. Siswa dengan kategori berkemampuan memiliki kenyaringan suara yang keras sehingga pembicaraan terdengar jelas dan bisa dipahami. Begitu juga dengan siswa kategori berkemampuan sedang memiliki tingkat kenyaringan suara yang bagus hanya suara terdengar datar sehingga kurang jelas maksud pembicarannya. Adapun siswa dengan kategori berkemampuan lambat memiliki tingkat kenyaringan suara yang sangat pelan dan terputus-putus.

Aspek Sikap gerak mimik (ekspresi); hasil pengamatan dan wawancara menunjukkan bahwa sikap gerak mimik siswa dalam berbicara juga menjadi salah satu aspek yang harus diperhatikan oleh siswa. Karena ekspresi wajah saat berbicara sangat mempengaruhi maksud dari pembicaraan. Siswa dengan kategori berkemampuan cepat memiliki ekspresi yang bagus dan sesuai dengan makna pembicaraan sesekali diberikan gerakan tangan untuk menambah penegasan dari pembicaraan yang disampaikan. Berdasarkan paparan hasil temuan penelitian yang sudah dideskripsikan di atas, menunjukkan bahwa kemampuan berbicara siswa kelas II E melalui model pembelajaran think talk write dengan subjek penelitian 6 orang siswa dengan kriteria 2 orang mewakili siswa dengan kategori berkemampuan cepat, 2 orang mewakili siswa dengan kategori berkemampuan sedang dan 2 orang mewakili siswa dengan kategori berkemampuan lambat menunjukkan bahwa kemampuan berbicara siswa memiliki perbedaan dari semua aspek. Hal ini menjadi refleksi bagi peneliti sekaligus guru untuk mencari solusi dari temuan penelitian ini agar kemampuan berbicara siswa bisa berkembang sesuai dengan harapan. Guru dituntut kreatif dalam menciptakan pembelajaran serta memilih model pembelajaran yang dapat meningkatkan kemampuan siswa khususnya kemampuan berbicara siswa.

\section{Kesimpulan}

Berdasarkan hasil penelitian yang telah dilakukan terkait analysis kemampuan berbicara siswa dengan model pebelajaran talk and write dapat disimpulkan bawah kemampuan berbicara pada siswa kelas awal dapat ditingkatkan dengan implementasi model pembelajaran talk and write dikelas awal. Berdasarkan paparan hasil temuan penelitian yang sudah dideskripsikan di atas, menunjukkan bahwa kemampuan berbicara siswa kelas II E melalui model pembelajaran think talk write dengan subjek penelitian 6 orang siswa dengan kriteria 2 orang mewakili siswa dengan kategori berkemampuan cepat, 2 orang mewakili siswa dengan kategori berkemampuan sedang dan 2 orang mewakili siswa dengan kategori berkemampuan lambat menunjukkan bahwa kemampuan berbicara siswa mengalami peningkatan melalui model pembelajaran think talk write. Refleksi bagi peneliti sekaligus guru untuk mencari solusi dari temuan penelitian ini agar kemampuan berbicara siswa bisa berkembang sesuai dengan harapan. Guru dituntut kreatif dalam menciptakan pembelajaran serta memilih model pembelajaran yang dapat meningkatkan kemampuan berbicara siswa.

\section{Daftar Pustaka}

Azlia Latae. 2019. Upaya meningkatkan kemampuan menulis permulaan siswa melalui metode SAS siswa kelas 1 SDN Tondo Kecamatan Bengku Barat Kabupaten Morowali. Jurnal Kreatif Tadulako Online Vol. 2 No. 4 ISSN 2354-614 
Depdiknas. 2004. Perpustakaan Perguruan Tinggi: Buku Pedoman, edisi ketiga. Jakarta: Depdiknas.

Gudu, 2015. Teaching Speaking Skills in English Language using Classroom Activities in Secondary School Level in Eldoret Municipality, Kenya. Journal of Education and Practice. No. 35 Vol. 6, $55-63$

Hapna.2014 Peningkatan Kemampuan Berbicara Siswa Melalui Presentasi Tugas Mandiri Dengan Power Point Dalam Diskusi Kelompok Di Kelas IX A1 SMP NEGERI 14 PALU. file:///C:/Users/Hp/Downloads/5-9-1- SM.pdf

Mardiyanis. 2007. Upaya Peningkatan Hasil Belajar Siswa Kelas IV SDN 001 Dengan Menggunakan Metode Diskusi Tahun Ajaran 2007/2008. Tidak Diterbitkan Akhadiah,

Providensia, Oktaviriana. 2015. Analisis
Kemampuan Berbicara MelaluiMetode Bercerita di TK Burder Melati Pontianak Kota. Pontianak:PAUD

Ratna Purwati,2014. Analisis Kemampuan Berpikir Kritis Siswa Dalam Menyelesaikan Masalah Persamaan Kuadrat Pada Pembelajaranmodel Creative Problem Solving. 5471-121 11005-1-10-20171003.pdf

Sabarti.1991/1992. Modul Bahasa Indonesia III. Jakarta: Departemen Pendidika dan Kebudayaan Dirjen

Samsul. 2018. Peningkatan Kemampuan Berbicara Siswa Kelas IV SDN 1 Galumpang Melalui Metode Latihan. Jurnal Kreatif Tadulako Online Vol. 4 No. 8 ISSN 2354-614X.

Sumantri, Mulyani. 2014. Perkembangan Peserta Didik. Jakarta: Universitas Terbuka 